Journal of Research in Technical Careers December 2018, Vol. 2, No. 2.

(C) Author(s)

\title{
Protective Factors Among Postsecondary Students Enrolled in a First-Generation Program
}

Ashley L. Austin ${ }^{\mathrm{a}}$, Stacy K. Vincent ${ }^{\mathrm{a}}$, Andrea Kirby ${ }^{\mathrm{b}}$

${ }^{a}$ University of Kentucky, ${ }^{b}$ Fayette County Public Schools

For generations, researchers have examined attributes that contribute to the adaptability of low socioeconomic youth. Attributes that help one become resilient are known as protective factors. The purpose of this descriptive study was to explore the protective factor(s) that contributed to the enrollment of first-generation, low-socioeconomic status (SES) students at a southern land-grant university. The population consisted of postsecondary students in a First Scholars program during the 2015-2016 academic year. The authors examine the existing literature on the effects of low SES on postsecondary education in order to explore what assists these students in maintaining a steadfast behavior. Recommendations are made for the recruitment of students who display a higher resiliency to be successful at the postsecondary level and for the First Scholars program on how to further enhance the program.

Keywords: resiliency, first-generation, low-SES, protective factors, postsecondary education

\section{Introduction}

In the 1960s, President Lyndon B. Johnson declared war on poverty. To show the severity of this issue, President Johnson scheduled a trip to Martin County, Kentucky, where poverty was at an all-time high to showcase the circumstances in which rural Americans lived (Bello, 2014). According to the United States Census Bureau (2013), 70.12\% of this Appalachian county's population was below the poverty level in 1960 . In comparison, $22.4 \%$ of Americans lived in poverty in the late 1950s (National Poverty Center, 2014).

By 1964, President Johnson addressed the nation:

Very often a lack of jobs and money is not the cause of poverty, but the symptom. The cause may lie deeper in our failure to give our fellow citizens a fair chance to develop their own capacities, in a lack of education and training, in a lack of medical care and housing, in a lack of decent communities in which to live and bring up their children. (Johnson, 1964, para. 25)

President Johnson's “war on poverty” was centered on four pieces of legislation: the Economic Opportunity Act, the Elementary and Secondary Education Act, the Food Stamp Act of 1964, and the Social Security Amendments of 1965. As a result of this "war on poverty," the United States poverty rate began to steadily decrease in the 1960 s, and by 1973 , the poverty rate had decreased to $11.1 \%$. However, by the 1980 s the poverty rate began to rise again and by 1983 had reached $15.2 \%$ or 35.3 million individuals (National Poverty Center, 2014). After decades of minimal fluctuation, the overall poverty rate began to decrease again in 2012; however, Kentucky's poverty rate did not see such a fluctuation (United States Census Bureau, 2013).

Need for the Study. The current widening economic gap among social classes is gaining national attention. The gap has been associated with the dwindling representation of low-socioeconomic status (SES) students in postsecondary education and high dropout rates in secondary education (Thomas \& Stockton, 2003).

In an effort to close the achievement gap in secondary and postsecondary academic success, researchers continue to examine factors connected to achievement among low-SES students. Many of the factors studied or discovered are considered external, including parental involvement (Ma, 2009), parental occupation (Leppel, Williams, \& Waldauer, 2001), parental encouragement (Sewell \& Shah, 1968), parental education level (Dubow, Boxer, \& Huesmann, 2009), family support (Seccombe, 2012), and peer associations (Stewart, 2008). Other factors have been internal, including student resilience (Werner, 2000) and career goals (Calcagno, Bailey, Jenkins, Kienzl, \& Leinbach, 2008).

Parental social class is a significant contributing factor to whether or not a child will go to college. Children with parents of high SES have greater access to higher education (Seccombe, 2012; Persell, 2010). Social class can determine what type of school the child will be able to attend, which relates to the quality of teachers, curriculum and teaching practices the school embraces (Persell, 2010). To widen the economic gap even further, 
research posits that counselors poorly perceive and expect less from low-SES students (Auwarter \& Aruguete, 2008).

Efforts Being Made at the Postsecondary Level. A variety of organized platforms, such as the First Scholars program, have swept across the country in an effort to assist low income students with their academic goals. Founded in 2008 by Eric Suder, the First Scholars program is a comprehensive program that seeks to develop cultural capital in less advantaged, firstgeneration college students through a four-year process (Pollard First Scholars, 2018). Annual themes (connect to campus, optimize the college experience, expand career and community opportunities, and transition to the future) are outlined for each of the four years of college. Each year the students focus on one objective and theme depending on what grade they are in (Pollard First Scholars, 2018). Learning objectives include:

1. First-Gen - Bridging the gaps, transforming challenges, creating opportunities, and accessing resources;

2. Self - Discovering potential, expanding awareness, utilizing strengths, and clarifying values and beliefs;

3. Success - Exploring possibilities, developing a personal vision, gaining experience, and building a skill set; and

4. Significance - Giving back, engaging personal passion, developing leadership, and making a difference (Center for First-Generation Student Success, 2018).

\section{Theoretical/Conceptual Framework}

Researchers have found first-generation, low-SES students that enroll and successfully transition into a higher educational institution to be resilient (Dubow, Boxer, \& Huesmann, 2009; Bradley \& Corwyn, 2005). Emmy Werner and Ruth Smith were among the first to explore the term resiliency. In the 1970s, the two used the term "resilient" to describe a cohort of poverty-stricken children in Kauai, Hawaii. Werner and Smith (1989) expanded resiliency research with a longitudinal study of multiple risk factors such as SES, family stability, and perinatal stress.

Early resiliency researchers focused on studying the individual and the individual's internal risk factors such as autonomy or high self-esteem (Luthar, Cicchetti, \& Becker, 2000), which could be attributed to helping the individual become resilient. This individual-themed lens for studying resiliency narrowed the field by limiting the investigation of how the individuals were becoming resilient (Hayhurst, Hunter, Kafka, \& Boyes, 2013).

As resiliency began to be explored in more depth, researchers realized external factors could contribute to an individual becoming resilient as well (Werner \& Smith, 1992). Additional research led to the creation of three factors associated with the "development of resilience: (1) attributes of the children themselves, (2) aspects of their families, and (3) characteristics of their wider social environments" (Luthar, Cicchetti, \& Becker, 2000 , p. 544). These three factors have been termed “protective factors” (Werner \& Smith, 1992).

Student success characteristics refer to the student's background (geographical location, parents' education level, SES, race, gender, etc.) and how likely that student is to enroll and succeed at a postsecondary institution. Perna and Titus (2005) found the most influential factor in determining college enrollment is parent education level. Oher researchers have expanded on this to include the most influential combination of factors in determining college enrollment is parent education level and SES (Dubow, Boxer, \& Huesmann, 2009).

After a first-generation, low-income student enters college, they often face difficulties with academic, cultural, and/or social transitions (Thayer, 2000). Due to the realization that college support can be limited, programs such as First Scholars require each student to develop an Individual Strategic Plan (ISP) tailored to each student's goals. This ISP serves as the primary tool to assess student characteristics. The ISP requires students to select activities and experiences that will assist in achieving their goals (Thayer, 2000).

The current study focuses on the First Scholars program at the University of Kentucky. The university serves as the land grant institution for the Commonwealth; a Commonwealth in which $60 \%$ of residents are low-SES with an unemployment rate that is above the federal average with only two of 120 counties above the nation's unemployment rate. The First Scholars program is not the only program to target first-generation college students at the University of Kentucky, but the only one where SES is a criterion for admission. Three characteristics (student success, tools to access, and support strategies) and the body of supportive research are what currently drives the First Scholars program (Thayer, 2000). Although the First Scholars program relies on research that examines factors influencing postsecondary enrollment (Dubow, Boxer, \& Huesmann, 2009; Werner, 2000; Werner \& Smith, 1992), limited research exists into the factors that influence the participants to remain in school and achieve academic success.

\section{Purpose and Research Objectives}

The purpose of this study was to describe the protective factor(s) that contribute to the enrollment of first-generation, low-SES students at the University of Kentucky. Tailoring a study to meet the needs of this specific program could provide more insight into the First Scholars population, problems the students face, and allow for the development of more diversified tools and programs to meet the needs of their students. 
The following research objectives were the focus of this study:

1. Describe selected characteristics of the firstgeneration, low-SES students in this program, specifically, gender, race/ethnicity, home residence, grade level, and grade point average (GPA).

2. Describe the protective factors present among the first-generation, low-SES students in this program.

3. Describe the protective factors present among the first-generation, low-SES students in this program by their college status.

\section{Method}

This study was descriptive and correlational by design. Descriptive research is used when a researcher wants to examine existing conditions (Fraenkel \& Wallen, 2006). Correlational research collects data on two or more variables and examines the relationship between those variables. In this study, the researcher examined which protective factor(s) assisted firstgeneration, low-SES students enrolling in a higher educational institution.

In this study, the population consisted of firstgeneration, postsecondary students enrolled in the First Scholars program during the 2015 - 2016 academic year $(\mathrm{N}=51)$. At the university in which this study was conducted, $18 \%$ of students are considered first- generation. In the researchers' attempt to gain census data, multiple methods of contact were implemented, which led to a tested population of $37(\mathrm{~N}=37)$.

The instrument used for this study contained two parts: part I consisted of protective factors and part II consisted of participant characteristics. The criteria of the 23 protective factors in part I were based on Werner's (2000) work on protective factors. The researcher contacted the founder of the developed protective factors (Werner \& Smith, 1992) for permission to modify and use these protective factors in the questionnaire. No protective factors were omitted, but some were reworded for better understanding, following information collected in a pilot study (e.g., "involvement in schools" was shortened to "school experiences"). The founder of the protective factors agreed to the modifications made. In part I of the questionnaire, participants indicated through a Likert scale from 1 to 5 , with 1 designated as "No Influence” and 5 designated as "Extremely Influential," regarding each protective factor's contribution to their success as a student within the college. In part II of the questionnaire, participants provided demographic information.

A panel of experts $(n=3)$ reviewed the questionnaire for face validity and a panel of students $(n=8)$ from similar backgrounds examined the questionnaire for content validity. Modifications were made following this review. Reliability is the extent to which an instrument produces accurate results (Phelan \& Wren, 2006). The reliability of the questionnaire was established using a

Table1. Characteristics of First-generation Participants $(\mathrm{N}=37)$

\begin{tabular}{lcc}
\multicolumn{1}{c}{ Characteristics } & $f$ & $\%$ \\
\hline Gender & 21 & 56.8 \\
Male & 16 & 43.2 \\
Female & & 73.0 \\
Ethnicity & 27 & 13.5 \\
White & 5 & 8.1 \\
Other & 3 & 5.4 \\
African American & 2 & 54.1 \\
Hispanic/Latino & & 37.8 \\
Home Residence & 20 & 8.1 \\
Suburban & 14 & 35.1 \\
Rural & 3 & 32.4 \\
Urban & & 32.4 \\
College Classification & 13 & \\
Sophomore & 12 & 24.3 \\
Junior & 12 & 18.9 \\
Senior & & 21.6 \\
Grade Point Average & 9 & 18.9 \\
3.75-4.0 & 7 & 10.8 \\
3.51-3.74 & 8 & 0 \\
3.26-3.50 & 7 & \\
3.01-3.25 & 4 & \\
$2.00-3.00$ & 0 & \\
$<2.00$ & & \\
\hline
\end{tabular}


Journal of Research in Technical Careers

Table 2. Protective Factors Influence on Successful College Transition $(\mathrm{N}=37)$

\begin{tabular}{lcc}
\hline Protective Factor & Mean & Range \\
\hline Achieve goals & 4.73 & $3.00-5.00$ \\
Ability to plan for future & 4.38 & $2.00-5.00$ \\
Focus on education & 4.32 & $2.00-5.00$ \\
Being independent & 4.24 & $1.00-5.00$ \\
Responsibilities & 4.14 & $1.00-5.00$ \\
Ability to be a self-starter & 4.03 & $1.00-5.00$ \\
Intelligence & 4.00 & $2.00-5.00$ \\
Upbringing & 3.92 & $1.00-5.00$ \\
Personality & 3.81 & $1.00-5.00$ \\
Positive self-concept & 3.70 & $1.00-5.00$ \\
School experiences & 3.65 & $1.00-5.00$ \\
Close friends & 3.51 & $1.00-5.00$ \\
Structure and rules & 3.43 & $1.00-5.00$ \\
Teacher(s) & 3.22 & $1.00-5.00$ \\
Physically distance self & 3.11 & $1.00-5.00$ \\
Faith & 3.11 & $1.00-5.00$ \\
Parents' education & 3.11 & $1.00-5.00$ \\
Caregiver relationship & 3.05 & $1.00-5.00$ \\
High School Activities & 2.97 & $1.00-5.00$ \\
Grandparents & 2.76 & $1.00-5.00$ \\
Siblings & 2.68 & $1.00-5.00$ \\
Hobbies/Special talents & 2.65 & $1.00-5.00$ \\
High school mentor(s) & 2.54 & $1.00-5.00$ \\
\hline
\end{tabular}

Scale: 1 = No Influence, 2 = Slightly Influential, 3 = Moderately Influential, 4 = Influential, and 5 = Extremely Influential

Table 3. Protective Factor Differences by Year in College $(\mathrm{N}=37)$

\begin{tabular}{|c|c|c|c|c|c|c|c|c|c|}
\hline & \multicolumn{3}{|c|}{ Sophomore } & \multicolumn{3}{|c|}{ Junior } & \multicolumn{3}{|c|}{ Senior } \\
\hline Protective Factor & $n$ & $\mathrm{M}$ & $S D$ & $n$ & $\mathrm{M}$ & $S D$ & $n$ & $\mathrm{M}$ & $S D$ \\
\hline High School Activities & 13 & 3.00 & 1.41 & 12 & 2.58 & 1.38 & 12 & $3.33^{*}$ & 1.23 \\
\hline Personality & 13 & 3.54 & 1.33 & 12 & 3.92 & .79 & 12 & $4.00 *$ & 1.13 \\
\hline Ability to be a self-starter & 13 & 3.92 & 1.19 & 12 & 4.00 & 1.04 & 12 & $4.17 *$ & 1.19 \\
\hline Intelligence & 13 & 3.62 & .87 & 12 & 4.17 & .83 & 12 & $4.25 *$ & .75 \\
\hline Physically distance self & 13 & 2.62 & 1.19 & 12 & 3.25 & 1.48 & 12 & $3.50^{*}$ & 1.44 \\
\hline Focus on education & 13 & $4.38 *$ & .65 & 12 & 4.25 & .87 & 12 & 4.33 & .65 \\
\hline Achieve goals & 13 & 4.54 & .78 & 12 & $4.83^{*}$ & .39 & 12 & $4.83^{*}$ & .39 \\
\hline Hobbies/Special talents & 13 & 2.38 & 1.33 & 12 & 2.67 & 1.07 & 12 & $2.92 *$ & 1.31 \\
\hline Positive self-concept & 13 & 3.62 & 1.12 & 12 & 3.42 & 1.00 & 12 & $4.08 *$ & .79 \\
\hline Ability to plan for future & 13 & 4.23 & .83 & 12 & $4.50 *$ & .90 & 12 & 4.42 & 1.00 \\
\hline Faith & 13 & 2.92 & 1.93 & 12 & 3.08 & 1.62 & 12 & $3.33^{*}$ & 1.61 \\
\hline Upbringing & 13 & 3.77 & 1.30 & 12 & 3.92 & 1.38 & 12 & $4.08 *$ & .90 \\
\hline Parents' education & 13 & $3.46^{*}$ & 1.39 & 12 & 2.75 & 1.48 & 12 & 3.08 & 1.44 \\
\hline Caregiver relationship & 13 & 2.77 & 1.69 & 12 & 2.92 & 1.68 & 12 & $3.50 *$ & 1.17 \\
\hline Grandparents & 13 & 2.69 & 1.25 & 12 & 2.17 & 1.28 & 12 & $3.42 *$ & 1.24 \\
\hline Siblings & 13 & 2.54 & 1.61 & 12 & $3.00 *$ & 1.48 & 12 & 2.50 & 1.38 \\
\hline Being independent & 13 & 3.92 & 1.19 & 12 & $4.67 *$ & .65 & 12 & 4.17 & .83 \\
\hline Structure and rules & 13 & 3.46 & 1.51 & 12 & 3.25 & 1.66 & 12 & $3.58 *$ & 1.31 \\
\hline Responsibilities & 13 & 4.15 & .80 & 12 & $4.17^{*}$ & 1.19 & 12 & 4.08 & 1.16 \\
\hline Close friends & 13 & 3.08 & 1.50 & 12 & 3.25 & 1.54 & 12 & $4.25 *$ & .87 \\
\hline Teacher(s) & 13 & 3.00 & 1.41 & 12 & 2.67 & 1.54 & 12 & $4.00 *$ & 1.04 \\
\hline School experiences & 13 & 3.62 & 1.12 & 12 & 3.42 & 1.38 & 12 & $3.92 *$ & 1.24 \\
\hline High school mentor(s) & 13 & 2.62 & 1.26 & 12 & 1.92 & 1.08 & 12 & $3.08 *$ & 1.44 \\
\hline
\end{tabular}

Scale: 1 = No Influence, 2 = Slightly Influential, 3 = Moderately Influential, 4 = Influential, and 5 = Extremely Influential;

*Protective factor is rated highest by participants in that year in college. 
scale was 0.81. According to Santos (1999), a Cronbach alpha score of 0.70 or higher should be considered acceptable.

The First Scholars coordinator invited the researchers to distribute the questionnaire at the conclusion of an end of semester meeting with all of the students. After the questionnaires were distributed through this paper/pencil face-to-face approach, the authors and the First Scholars coordinator contacted all non-responsive participants by email in order to prevent non-response error, "which occurs when a significant number of people in the survey sample do not respond to the questionnaire" (Salant \& Dillman, 1994, p. 20). Salant and Dillman (1994) consider a response rate under 60-70 percent as an indicator of non-response error. The authors secured a $72 \%$ response rate.

\section{Results}

Research Objective 1: Describe selected characteristics of the first-generation, low-SES students in this program, specifically, gender, race/ethnicity, home residence, grade level, and GPA. $56.8 \%(\mathrm{f}=21)$ of respondents are male, and $73.0 \%(\mathrm{f}=27)$ are White. A majority of participants ( $f=20 ; 54.1 \%$ ) considered their home residence to be in a suburban setting. Of the participants, the majority were sophomores ( $f=13$; $35.1 \%$ ), followed by juniors ( $f=12$; $32.4 \%$ ) and seniors ( $\mathrm{f}=12 ; 32.4 \%$ ). The leading cumulative GPA reported by the participants ( $\mathrm{f}=10$; $27.0 \%$ ) fell in the range of 3.26-3.50. Additional demographic characteristics of participants can be found in Table 1.

Research Objective 2: Describe the protective factors present among the first-generation, low-SES students in this program. Achieving goals $(M=4.73)$ was identified as the most influential protective factor, followed by the ability to plan for one's future $(M=4.38)$. The ability to focus on one's education had a mean score of 4.32, followed by being independent $(M=4.24)$ and then responsibilities $(M=4.14)$, being a self-starter $(M=$ 4.03), and intelligence $(M=4.00)$. Siblings $(M=2.68)$, hobbies $(M=2.65)$, and high school mentors $(M=2.54)$ were identified by the respondents as the least influential protective factor listed. Mean values for the influence of each protective factor can be reviewed in Table 2 .

Research Objective 3: Describe the protective factors present among the first-generation, low-SES students in this program by their college status. For each protective factor, the average value for perceived influence of each factor was calculated for participants in each year of the First Scholars program. Of the 23 protective factors, seniors rated 17 of the protective factors higher in influence when compared to students in other years in college while juniors identified four of the protective factors to be more influential. Sophomores accredited only two of the protective factors to be higher than the freshman, sophomores, and seniors (i.e. Focus on Education; Parent's Education). The value that is on average higher in a particular year in college as compared to other years is highlighted in Table 3 using an asterisk.

\section{Conclusions, Recommendations, and Implications}

Researchers have found students enrolled in collegiate programs/activities perform better academically than students not enrolled in extracurricular activities (Calcagno, Bailey, Jenkins, Kienzl, \& Leinbach, 2008). This suggests that allocating funding to and continuing programs such as the First Scholars program helps students to stay focused academically, thus implying that the high-risk students identified in these programs would continue to stay focused in their studies and have a higher success rate at the collegiate level.

The five protective factors that were most likely to be ranked as influential were Achieving Goals, Ability to Plan, Focus on Education, Being Independent, and Responsibilities. All five of these protective factors are considered internal factors, coming from within the individual versus within the family or within the community (Werner \& Smith, 1992). Although additional research needs to be conducted to confirm similar findings, it is recommended that the university begin to explore other forms of admission processes and become less dependent on entry exams as these exams do not correlate to resiliency (Engle, Bermeo, \& O’Brien, 2006) for low-income students. One path for possible implementation in regards to admission processes are the use of student interviews, essays, or utilization of Werner's instrument to probe for protective factors among potential students.

While internal protective factors are learned at a young age, high school programs, such as student organizations, clubs and sports, can teach protective factors like Responsibilities and Achieving Goals (Schexnider, 2013). Collaborations between the university and youth organizations could allow adolescents to gain additional protective factors more successfully and to use their already established protective factors, which they gained through their lived experiences.

The five protective factors that were ranked as least influential were High School Activities, Grandparents, Siblings, Hobbies/Special Talents, and High School Mentors. The majority of the least influential protective factors are considered familial and communal. Although familial and communal support may still contribute to the overall success of the student, the participants in this study value tangible, external accomplishments as more of an influence in their academic success (Werner, 1995). Nickerson, Diener, and Schwarz (2010) explain how an upperclassmen may credit their consistent record of 
academic success to internal factors, such as Hard Work, rather credit their parental upbringing over their adolescent years.

Internal protective factors are perceived as being extremely important to the resiliency of the low-SES students in this study. Based on these results, postsecondary undergraduate degree programs should consider creating collaborations within their colleges that establish pedagogical and andragogic trainings to faculty and staff regarding how to work with students lacking internal protective factors. Establishing programs that create communal protective factors is recommended as an effort to help make up for the lack of internal protective factors by bolstering communal support and relationships. Awareness training on personal protective factors and methods of how to lean upon them more could be added to summer orientation programs for incoming freshmen. Similarly, Individual Strategic Plans, as assigned by the First Scholars program, should continue to be used as a quality initiative that encourages students to stay focused within the context of the goals they have established. This is especially important given that participants scored Achieving Goals highest among the 23 protective factors in this study. The authors recommend that students continue to develop ISPs and that they be shared with the student's academic advisor.

\section{References}

Auwarter, A. E., \& Aruguete, M. S. (2008). Counselors perceptions of students who vary in gender and socioeconomic status. Social Psychology of Education, 11, 389-395. https://doi.org/10.1007 /s11218-008-9056-0

Bradley, R. H., \& Corwyn, R. F. (2005). Caring for children around the world: A view from HOME. International Journal of Behavioral Development 6, 468-478.

Calcagno, J. C., Bailey, T., Jenkins, D., Kienzl, G., \& Leinbach, T. (2008). Community college student success: What institutional characteristics make a difference? Economics of Education Review, 27(6), 632-645. https://doi.org/10.1016/j.econedurev.2007 .07 .003

Center for First-Generation Student Success (2018). First Scholars Steps to Success. Retrieved on November 10, 2018, from https://firstgen.naspa.org /program/first-scholars-steps-to-success

Dubow, E. F., Boxer, P., \& Huesmann, L. R. (2009). Long-term effects of parents' education on children's educational and occupational success: Mediation by family interactions, child aggression, and teenage aspirations. Merrill Palmer Q (Wayne State University Press), 55(3), 224-249. https://doi .org/10.1353/mpq.0.0030

Engle, J., Bermeo, A., \& O’Brien, C. (2006). Straight from the source: What works for first-generation college students. The Pell Institute for the Study of
Opportunity in Higher Education. Retrieved May 4, 2014, from https://www.tgslc.org/pdf/files-sfts _what_works.pdf

Fraenkel, J., \& Wallen, N. (2006). How to design and evaluate research in education (6th ed.). New York, NY: McGraw-Hill.

Johnson, L. B. (1964). First State of the Union Address. Retrieved December 3, 2014, from http:// www.americanrhetoric.com/speeches/lbj1964state oftheunion.htm

Johnson, L. B. (1964). Remarks Upon Signing the Economic Opportunity Act. August 20, 1964. Online by Gerhard Peters and John T. Woolley, The American Presidency Project. Retrieved from http://www.presidency.ucsb.edu/ws/?pid=26452

Leppel, K., Williams, M. L., \& Waldauer, C. (2001). The impact of parental occupation and socioeconomic status on choice of college major. Journal of Family and Economic Issues, 22(4), 373-394. https://doi.org/10.1023 /A:1012716828901

Ma, Y. (2009). Family socioeconomic status, parental involvement, and college major choices-gender, race/ethnic, and nativity patterns. Sociological Perspectives, 52(2), 211-234. https://doi.org/10 .1525/sop.2009.52.2.211

Nickerson, C., Diener, E., \& Schwarz, N. (2010). Positive affect and college success. Journal of Happiness Studies, 12(4), 717-764. https://doi .org/10.1007/s10902-010-9224-8

Persell, C. H. (2010). Social class and educational equality ( $7^{\text {th }}$ Ed.). J. A. Banks \& C. A. M. Banks (Eds.). Multicultural education issues and perspectives (pp. 84-106). Hoboken, NJ: John Wiley \& Sons.

Phelan, C. \& Wren, J. (2006). Exploring reliability in academic assessment. Retrieved February 12, 2015, from https://www.uni.edu/chfasoa /reliabilityandvalidity.htm

Pollard First Scholars. (2018). Pollard First Scholars at University of Kentucky. Retrieved November 10, 2018, from https://www.uky.edu/firstgeneration /pollard-scholars-program

Salant, P. \& Dillman, D. (1994). How to conduct your own survey. New York, NY: John Wiley \& Sons, Inc.

Santos, J. R. A. (1999). Cronbach's alpha: A tool for assessing the reliability of scales. Journal of Extension [On-line], 37(2).

Schexnider, M. (2013, October). Measuring teacher quality: Do teachers impact students' adult outcomes? Retrieved from http:// chicagopolicyreview.org/2013/10/22/measuringteacher-quality-do-teachers-impact-students-adultoutcomes-2/

Seccombe, K. (2012). Families and their social worlds. Boston, MA: Pearson Education,

Stewart, E. B. (2008). School structural characteristics, student effort, peer associations, and parental 
involvement: The influence of school- and individual-level factors on academic achievement. Education and Urban Society 40(2), 179-204. https://doi.org/10.1177/0013124507304167

Sewell, W. H., \& Shah, V. P. (1968). Social class, parental encouragement, and educational aspirations. American Journal of Sociology, 73, 559-572.

Thayer, P. B. (2000). Retention of Students from First Generation and Low Income Backgrounds. (Report No. 088331). Washington, DC: United States Department of Education.

Thomas, J., \& Stockton, C. (2003). Socioeconomic status, race, gender, \& retention: Impact on student achievement. Essays in Education, 57(10). https:// doi.org/10.1016/j.jaac.2018.09.414

Werner, E. E. (1995). Resilience in development. Current Directions in Psychological Science, 4(3), 81-85.

Werner, E. (2000). Protective Factors and Individual Resilience. In J. P. Shonkoff and S. J. Meisels (Eds.), Handbook of Early Childhood Intervention (pp. 115-132). Cambridge: Cambridge University Press.

Werner, E. E., \& Smith, R. S. (1992). Overcoming the odds: High risk children from birth to adulthood. Ithaca, NY: Cornell University Press. 